\title{
Electoral College, 1804 - 2008: Winner's Propensity and Electoral Entity Vote Size
}

\author{
Jack E. Riggs ${ }^{1, *,}$, Gerald R. Hobbs ${ }^{2}$ and Todd H. Riggs ${ }^{3}$ \\ ${ }^{1}$ Department of Neurology, West Virginia University, Morgantown, WV, USA \\ ${ }^{2}$ Department of Statistics, West Virginia University, Morgantown, WV, USA \\ ${ }^{3}$ United States Army, Ft. Campbell, KY, USA
}

\begin{abstract}
The Electoral College two electoral vote add-on and winner-take-all methodologies are generally thought to give less populous and more populous states an advantage in U.S. presidential elections. This study examined whether electoral entities with the least and most electoral votes were more likely to have cast their votes for the winning candidate; and if so, whether this winner's propensity has determined the outcome. In the 52 U.S. presidential elections from 1804 though 2008, electoral entities with the least (Quartile 1) and most (Quartile 4) electoral votes were significantly (p $<0.001$ ) more likely to have cast their votes for the winning candidate than were electoral entities in the two intermediate electoral vote quartiles (Quartiles 2 and 3). However, in the 17 "close" U.S. presidential elections (defined as when the wining candidate received less than 60 percent of the total potential electoral votes), electoral entities in Quartiles 1 and 4 were not significantly more likely $(\mathrm{p}=0.7339)$ to have cast their votes for the winner than were electoral entities in Quartiles 2 and 3 . Although electoral entities with the least and most electoral votes were significantly more likely to have voted for the winner in "all" U.S. presidential elections, this propensity was present only in "landslide" elections and was not present in "close" Electoral College elections. These findings suggest that the net effect of the Electoral College has not been to give the least and most populous states an advantage in determining the winner in U.S. presidential elections since any such winner's propensity was only observed in "landslide" victories.
\end{abstract}

Keywords: Electoral College, history, U.S. presidential elections, voting.

\section{INTRODUCTION}

The two electoral vote add-on was a crucial compromise in the creation of the Electoral College (Gregg 2001; Harvard Law Review 2001). This compromise gave less populous states a proportionally greater influence in electing the president. The winner-take-all methodology of awarding electoral votes, currently used by all states except Maine and Nebraska, may give more populous states an advantage in U.S. presidential elections (Harvard Law Review 2001; Longley and Dana 1984; Sterling 1978). Based upon the electoral vote distribution present in 2000, these two Electoral College methodologies produced an average winner's advantage of 29.45 electoral votes in one million random two-candidate simulated elections (Riggs, Hobbs, and Riggs 2009). This winner's advantage in random elections in the Electoral College occurs as a result of the aggregation of electoral votes in the Electoral College (Riggs, Hobbs, and Riggs 2009; Miller 2011). Thus, the methodologies used by the Electoral College produce a theoretical winner's advantage favoring smaller and larger populous states. This study of U.S. presidential elections from 1804 though 2008

\footnotetext{
*Address correspondence to this author at the Department of Neurology, West Virginia University, Morgantown, WV 26506-9180, USA; Tel: 304-293-3527; Fax: 304-293-3352; E-mail: jriggs@wvu.edu

$\wedge$ The opinions and assertions herein are those of the authors and do not necessarily reflect those of the United States Army.
}

examined whether electoral entities with the least and most electoral votes were more likely to have cast their electoral votes for the winning candidate, and if so, whether this winner's propensity determined the outcome.

\section{MATERIALS AND METHODOLOGY}

In order to test these two hypotheses, U.S. presidential Electoral College elections from 1804 through 2008 were analyzed (www.archives.gov). The 1804 election was selected as the initial election since that was the first presidential election that occurred following enactment of the Twelfth Amendment that separated Electoral College votes for President and Vice-President. For each of these 52 U.S. presidential elections, electoral entities were separated into four quartiles based upon the total number of electoral votes that each entity was allotted. Quartiles were selected so as increase the number of electoral entities in each category and have a category with the most and least electoral vote entities and a comparable size of categories that did not have the most and least electoral vote entities. Quartile assignment was made for each presidential election. Quartiles were created so as to most evenly divide the electoral entities with the caveat that all electoral entities with the same number of allotted electoral votes had to be assigned to the same quartile. Quartile 1 was the quartile with electoral entities with the least allotted electoral votes. Quartile 4 was the quartile with electoral entities with the most allotted electoral votes. 
In the 52 U.S. presidential elections from 1804 to 2008, there were 2079 electoral entities which cast votes for President of the United States in the Electoral College. Of these 2079 voting occasions, 544 were assigned to Quartile 1; 565 were assigned to Quartile 2; 487 were assigned to Quartile 3; and 483 were assigned to Quartile 4. The reason that Quartiles 1 and 2 had larger numbers assigned to them was that electoral entities with smaller allotted electoral votes were much more numerous than electoral entities with larger numbers of electoral votes, and electoral entities with the same number of allotted electoral votes in each election had to be assigned to the same quartile. There were 1024 voting occasions for electoral entities in Quartiles 1 and 4, and 1052 voting occasions for electoral entities in Quartiles 2 and 3. This difference was not significant.

\section{RESULTS}

Each electoral entity in these 52 U.S. presidential elections either voted for the presidential winner or did not vote for the winner. In 24 out of these 2079 voting occasions, electoral entities split their electoral vote. On those few occasions, the electoral entity was judged to have voted for the winner if the majority of their electoral votes were cast for the winner. Table 1 displays the frequency and proportion of time that electoral entities in each quartile voted for the winner in these 52 presidential elections. As shown, electoral entities in Quartiles 1 and 4 voted for the winner 71.14\% and $74.95 \%$ of the time respectively. Electoral entities in Quartiles 2 and 3 voted for the winner $67.43 \%$ and $65.30 \%$ of the time respectively. The p-value (likelihood ratio) that the proportion of voting for the winner in these four quartiles was the same was 0.0051 . Thus, the likelihood of voting for the winner was significantly different in the quartiles. Moreover, Quartiles 1 and 4 (entities with the least and most electoral votes) appeared to be more likely to have voted for the winner (Table 1).

In order to test whether electoral entities with the least and most electoral votes were more likely to have voted for the winner, Quartiles 1 and 4 were combined, and Quartiles 2 and 3 were combined (Table 2). As shown, combined electoral entities in Quartiles 1 and 4 voted for the winner 72.93\% of the time, and combined electoral entities in Quartiles 2 and 3 voted for the winner $66.44 \%$ of the time. This difference was highly significant, with the p-value (likelihood ratio) equal to 0.0013 .

Between 1804 and 2008, there were 21,951 potential electoral votes to be cast in the Electoral College in those 52 U.S. presidential elections. In those 52 elections, 15,750 electoral votes (or $71.75 \%$ ) were cast for the winner. Thus, the average U.S. presidential election was a large or "landslide" victory for the winner. The statistically significant propensity of small and large electoral vote entities to cast their vote for the winner is only meaningful if that propensity actually determined the outcome of U.S. presidential elections. Accordingly, we segregated U.S. presidential elections into non-close and close elections. A close election was defined as a presidential election in which the winner received less than $60 \%$ of possible electoral votes in the Electoral

Table 1. Electoral Entities Casting Votes in the Electoral College in U.S. Presidential Elections (1804 - 2008) Sorted by Electoral Entity Vote Size (Quartile 1 Being the Smallest Electoral Vote Size) and Also sorted by Whether Election was Close or Not

\begin{tabular}{|c|c|c|c|}
\hline Elections & Total Electoral & Number Voted & Proportion \\
\hline Quartile 1 & 544 & 387 & 0.7114 \\
\hline Quartile 2 & 565 & 381 & 0.6743 \\
\hline Quartile 4 & 483 & 362 & 0.7495 \\
\hline Non-Close & 1415 & 1086 & 0.7675 \\
\hline Quartile 1 & 376 & 296 & 0.7872 \\
\hline Quartile 2 & 387 & 280 & 0.7235 \\
\hline Close & 664 & 362 & 0.5452 \\
\hline Quartile 1 & 168 & 91 & 0.5417 \\
\hline Quartile 2 & 178 & 77 & 0.5674 \\
\hline Quartile 3 & 158 & 78 & 0.5063 \\
\hline Quartile 4 & 160 & 90 & 0.5452 \\
\hline
\end{tabular}


Table 2. Electoral Entities Casting Votes in the Electoral College in U.S. Presidential Elections (1804 - 2008) Sorted by Whether Electoral Entity Vote Size was in the Smallest and Largest Quartiles (Quartiles 1 and 4) or not (Quartiles 2 and 3 ) and Also Sorted by Whether the Election was Close or Not

\begin{tabular}{|c|c|c|c|}
\hline Elections & Total Electoral & Number Voted & Proportion \\
\hline & Entity Number & For Winner & 1448 \\
\hline \hline All & 2079 & 749 & 0.6965 \\
\hline Quartiles 1 \& 4 & 1027 & 699 & 0.7293 \\
\hline Quartiles 2 \& 3 & 1052 & 1086 & 0.6644 \\
\hline Non-Close & 1415 & 568 & 0.7675 \\
\hline Quartiles 1 \& 4 & 699 & 518 & 0.8126 \\
\hline Quartiles 2 \& 3 & 716 & 362 & 0.7235 \\
\hline Close & 664 & 181 & 0.5452 \\
\hline Quartiles 1 \& 4 & 328 & 181 & 0.5518 \\
\hline Quartiles 2 \& 3 & 336 & & 0.5387 \\
\hline
\end{tabular}

College. A non-close (or "landslide") election was defined as a presidential election in which the winner received $60 \%$ or more of possible electoral votes in the Electoral College. By this definition, there were 17 close U.S. presidential elections from 1804 through 2008. Those close presidential elections were 1812, 1824, 1836, 1848, 1856, 1860, 1876, 1880, 1884, 1888, 1916, 1948, 1960, 1968, 1976, 2000, and 2004. Table 1 also displays, by quartile, the frequency and proportion of time that electoral entities in the 35 non-close and 17 close U.S. presidential elections voted for the winner. As shown (Table 1), electoral entities in Quartiles 1 and 4 voted for the winner $78.72 \%$ and $84.21 \%$ of the time respectively in non-close presidential elections. Electoral entities in Quartiles 1 and 4 voted for the winner $54.17 \%$ and $54.52 \%$ of the time respectively in close presidential elections. Electoral entities in Quartiles 2 and 3 voted for the winner 72.35\% and $72.34 \%$ of the time respectively in non-close presidential elections (Table 1). Electoral entities in Quartiles 2 and 3 voted for the winner $56.74 \%$ and $50.63 \%$ of the time respectively in close presidential elections (Table 1). The p-value (likelihood ratio) that the proportion of voting for the winner in non-close presidential elections in these four quartiles was the same was 0.0002. Thus, the likelihood of voting for the winner was significantly different in the quartiles for nonclose presidential elections. The p-value (likelihood ratio) that the proportion of voting for the winner in close presidential elections in these four quartiles was the same was 0.6784 . Thus, the likelihood of voting for the winner was not significantly different in the quartiles for close presidential elections.

Quartiles 1 and 4, electoral entities with the least and most electoral votes, appeared more likely to have voted for the winner in non-close U.S. presidential elections, but not in close U.S. presidential elections (Table 1). In order to test whether electoral entities with the least and most electoral votes were more likely to have voted for the winner in nonclose versus close U.S. presidential elections, Quartiles 1 and 4 were combined in non-close and close presidential elections, and Quartiles 2 and 3 were combined in non-close and close presidential elections (Table 2). Combined electoral entities in Quartiles 1 and 4 voted for the winner 81.26\% of the time in the 35 non-close presidential elections and $55.18 \%$ of the time in the 17 close presidential elections (Table 2). Combined electoral entities in Quartiles 2 and 3 voted for the winner $72.35 \%$ of the time in the 35 non-close presidential elections and $53.87 \%$ of the time in the 17 close presidential elections (Table 2). Compared to Quartiles 2 and 3, Quartiles 1 and 4 were significantly more likely to have voted for the winner in non-close U.S. presidential elections; p-value (likelihood ratio) less than 0.001. Conversely, compared to Quartiles 2 and 3, Quartiles 1 and 4 were not more likely to have voted for the winner in close U.S. presidential elections; p-value (likelihood ratio) equal to 0.7339.

Thus, the winner's propensity of the smallest and largest electoral vote entities in the Electoral College was only present in "landslide" presidential elections and was not present in "close" presidential elections.

\section{DISCUSSION}

Although previous studies of "bias" in the Electoral College have focused on factors such as swing ratio, partisan bias, and unequal voter representation per electoral vote between the various states (Berthoud 1997; Brams and Davis 1975; Destler 1996; Garand and Parent 1991; Grofman et al. 1997; Harvard Law Review 2001; Holbrook and Van Dunk 1993; Longley and Dana 1984; Nelson 1974; Shaw 1999; Sterling 1978), analysis of the "rules" of the Electoral College suggest a theoretical winner's advantage due to electoral vote clumping as a result of the two electoral vote add-on and winner-take-all methodologies (Riggs, Hobbs, and Riggs 2009; Miller 2011). Those Electoral College methodologies are thought to give small and large electoral vote entities a greater advantage in presidential elections. This analysis was performed to determine if small and large electoral vote entities were actually more likely to have voted for the winner in U.S. presidential elections. The results demonstrated that small and large electoral vote entities were significantly more likely to have voted for the winner. However, when U.S. presidential elections were separated or stratified into non-close and close elections, there was no winner's propen- 
sity for small and large electoral vote entities in close U.S. presidential elections.

\section{CONCLUSION}

This paper purposely avoided engaging in the debate of whether the election of the president of the United States should continue to be determined by the Electoral College or determined by national popular vote. The purpose of this analysis was to report the finding that although there has been a significant winner's propensity in the Electoral College for small and large electoral vote entities in "all” 52 U.S. presidential elections from 1804 through 2008, this propensity was only present in the 35 "landslide" elections and was absent in the 17 "close" U.S. presidential elections, where such a winner's advantage, or bias, could have played a role in determining the outcome.

\section{CONFLICT OF INTEREST}

None declared.

\section{ACKNOWLEDGEMENT}

None declared.

\section{REFERENCES}

Berthoud, J. E. (1997). The electoral lock thesis: the weighting bias component. PS: Political Science and Politics, 30(2), 189-193.
Brams, S. J., \& Davis, M. D. (1974). The 3/2's rule in presidential campaigning. American Political Science Review, 68(1), 113-134.

Destler, I. M. (1996). The myth of the 'electoral lock'. PS: Political Science and Politics, 29(3), 491-494.

Garand, J. C., \& Parent, T. W. (1991). Representation, swing, and bias in U.S. presidential elections, 1872-1988. American Journal of Political Science, 35(4), 1011-1031.

Gregg II, G. L. (Ed.). (2001). Securing Democracy, Why We Have an Electoral College. Wilmington: ISI Books.

Grofman, B., Brunell, T., \& Campagna, J. (1997). Distinguishing between the effects of swing ratio and bias on outcomes in the US Electoral College, 1900-1992. Electoral Studies, 16(4), 471-487.

Harvard Law Review (2001). Rethinking the Electoral College debate: the framers, federalism, and one person, one vote. Harvard Law Review, 114(8), 2526-2549.

Holbrook, T. M., \& Van Dunk, E. (1993). Electoral competition in the American states. American Political Science Review, 87(4), 955962.

Longley, L. D., \& Dana Jr., J. D. (1984). New empirical estimates of the biases of the Electoral College for the 1980's. Western Political Quarterly, 37(1), 157-175.

Miller, N. R. (2011). Banzhaf voting power, random elections, and the Electoral College winner's advantage. Electoral Studies, 30(4), 829833.

Nelson, M. C. (1974). Partisan bias in the Electoral College. Journal of Politics, 36(4), 1033-1048.

Riggs, J. E., Hobbs, G. R., \& Riggs, T. H. (2009). Electoral College winner's advantage. PS: Political Science and Politics, 42(3), 353-357.

Shaw, D. R. (1999). The methods behind the madness: presidential Electoral College strategies, 1988-1996. Journal of Politics, 61(4), 893-913.

Sterling, C. W. (1978). The Electoral College biases revealed: the conventional wisdom and game theory models notwithstanding. The Western Political Quarterly, 31(2), 159-177. 